IZA DP No. 4349

Does Racism Affect a Migrant's Choice of Destination?

Ruby Henry

August 2009 


\title{
Does Racism Affect a Migrant's Choice of Destination?
}

\author{
Ruby Henry \\ Toulouse School of Economics \\ and IZA
}

Discussion Paper No. 4349

August 2009

\author{
IZA \\ P.O. Box 7240 \\ 53072 Bonn \\ Germany \\ Phone: +49-228-3894-0 \\ Fax: +49-228-3894-180 \\ E-mail: iza@iza.org
}

\begin{abstract}
Any opinions expressed here are those of the author(s) and not those of IZA. Research published in this series may include views on policy, but the institute itself takes no institutional policy positions.

The Institute for the Study of Labor (IZA) in Bonn is a local and virtual international research center and a place of communication between science, politics and business. IZA is an independent nonprofit organization supported by Deutsche Post Foundation. The center is associated with the University of Bonn and offers a stimulating research environment through its international network, workshops and conferences, data service, project support, research visits and doctoral program. IZA engages in (i) original and internationally competitive research in all fields of labor economics, (ii) development of policy concepts, and (iii) dissemination of research results and concepts to the interested public.
\end{abstract}

IZA Discussion Papers often represent preliminary work and are circulated to encourage discussion. Citation of such a paper should account for its provisional character. A revised version may be available directly from the author. 


\section{ABSTRACT}

\section{Does Racism Affect a Migrant's Choice of Destination?*}

I explicitly introduce racial conflict and cultural attitudes on racial diversity as determinants of destination choice to test their continued relevance to African Americans. I construct several measures of racial intolerance towards African Americans using hate crime activity and the feelings of white Americans about race extracted from a national social attitudes survey. Recognizing that African American migration may actually spawn hate crimes against them, I use a control function method with assaults on white police officers and hate crimes against Jews as instruments to correct for potential endogeneity. The results show that the probability of African American migrants choosing a city is significantly reduced by per capita hate crimes against them, the level of race-based crimes against them, by racially intolerant attitudes held by whites, and by poor evolution in whites' feelings about racial diversity - all regardless of the region in which a city is located. Also striking is the previously undocumented divide among African Americans with respect to region, after controlling for racial intolerance. Those starting in the North exhibit an extreme distaste for the South at the margin, which contrasts sharply to the extreme taste for the South displayed by African Americans originating in the South.

JEL Classification: J15, J61, R23, C25

Keywords: racial violence, discrimination, migration, conditional logit

Corresponding author:

Ruby Henry

IZA

P.O. Box 7240

53072 Bonn

Germany

E-mail: rhenry@post.harvard.edu

\footnotetext{
*I thank Gilles Saint-Paul, Pierre Dubois, Guido Friebel, Paul Seabright, Pierre-Andre Chiappori, Lena Edlund, Thierry Magnac, Emmanuelle Auriol, Jeffrey Williamson, Alexander Gelber, Jean Lee, Alexander White, and Márton Csillag and seminar participants at 2008 CEPR/IZA ESSLE, 2009 IZA Summer School, Toulouse School of Economics, and Columbia. This project was supported by CEPREMAP. All opinions, conclusions, and errors are mine.
} 


\section{Introduction}

The early 1970's saw the first reversal of the South consistently losing African Americans since the Civil War. By the latest available data, most Southern states no longer show net losses of African Americans. What are the implications of this reversal in population shifts? Previous research shows significant decline in racial wage discrimination in the South over the past 40 years. As African Americans move South to take advantage of this progress, this will likely have implications for racial wage equality in all regions. Furthermore, African American migrants to the South differ substantially from those already established there. The tide of southern-born African Americans who migrated North before the 1970's were typically less educated and less fortunate than those already in the North. The exact opposite is true for the modern-day migration pattern. Today, African American migrants to the South are much more educated and have higher incomes than those already in the South. In addition, political consequences arise. Voting patterns and participation may differ systematically between these groups owing to educational background and previous residency in different regions. In fact, although a minority of African Americans claims a Republican Party affiliation, the probability of such affiliation is higher for African Americans living in the South.

In addition to the numerous implications of this recent development in the migration pattern, another point arises: given the long history of African American departure from the South and that racial intolerance against African Americans remains higher in the South (See Map 1), why are African Americans migrants in the North much more likely to relocate to the South than any other race group today ${ }^{1}$ ? Given these findings, the following research question naturally arises: can it be that African American migrants are still deterred by racism?

To answer this question, I make four key contributions to the economic literature on general migration and on African American migration. My first contribution is to intro-

\footnotetext{
${ }^{1}$ Migrants composed $14.6 \%$ of all whites and $11.4 \%$ of all African Americans.
} 
duce racial tension as a determinant of city choice in an individual utility maximization framework, using Census micro data (IPUMS) and the Current Population Survey (CPS). Though most studies on African American migration mention racial tension in the South, none have explicitly incorporated it into a model of destination choice.

My second contribution is the construction of several measures of racial intolerance towards African Americans using anti-African American hate crime activity and the responses of white Americans to questions on race from a national social attitudes survey. Though Tolnay and Beck [1992] find a positive correlation between lynching and the net out-migration rate of African Americans in Southern counties; this falls short of my contributions in two ways. The primary shortcoming is that they cannot show hate crimes increased net out-migration to the North or any other area with fewer hate crimeswithout micro data one could instead conclude that these Southern residents moved to neighboring counties in the South and/or counties with equal hate crime activity. The other shortcoming is the analysis of aggregate flows rather than the individual location decision, which also stems from the lack of micro data.

Thirdly, I contribute an analysis of the hedonic prices of racism outside the labor market. I calculate the hourly wage supplement African Americans require for increased exposure to hate crimes and the racist attitudes of whites.

Finally, while almost all studies of African American domestic migration examine regional movement from the South to North and focus on historical time periods, my fourth contribution is, instead, to document African American migration in the late 1990s at the regional, state, and metro area levels and include over 125 metropolitan areas in the destination choice set.

Every U.S. Census of Population after the Civil War through 1960 shows African Americans slipping away from the South. The destruction of land and property, disorganization, and the upheaval of social order in the Civil War aftermath, suggest that economic opportunities were more promising in the North in the short term. The "human 
capital theory" of Sjaastad [1962] would be sufficient to explain northward migration given the expected earnings stream differential between the two regions. In addition, the racial resentment, social apartheid, and level of hate crimes that ensued for several decades in the South were arguably a long term "push" effect. The Census of 1860 shows that the highest concentrations of African Americans were in Southern states and that 95 percent of African Americans in the United States lived in the South (See Map 2 and Chart 1). By 1960, this share dropped dramatically to 60 percent while the Southern share of the total white population decreased only modestly. Migration played a key role in this declining proportion of African Americans in the South (See Table 5a). The net outflow of African Americans from the South was often greater than that of whites. Furthermore, the net loss started as 2 percent of the South's total African American population in 1870 and rose to 18 percent in 1940 (See Table 5b).

Indeed, the most commonly cited determinants of African American migration after the Civil War are the "pull" of economic opportunities in the North and, despite rigorous treatment, the "push" of racial discrimination in the South. In this light, it is informative that Heckman [1990] argues that the favorable conditions in the 1970-1980 Southern labor market were key to even the national economic progress of African Americans. Vigdor [2006] provides regional documentation of Northern-born African Americans migrating to the South, illustrates that the racial earnings gap in the South had converged to that in the North, and shows that the narrowing of the racial wage gap was more rapid in the South than in the North-all in the 1990s. This turn of events suggests that the economic "pull" factor is still relevant in the city choice, but whether African Americans are still "put off" by racism is less evident. Specifically, how does racial intolerance against African Americans affect their probability of choosing a city?

The results show that African American migrants from the North and South are both significantly deterred by hate crime activity against them and by racially intolerant attitudes towards them held by whites, regardless of the region in which a city is located. 
In fact, the negative racial attitudes of whites has an effect comparable in size to the unemployment rate. Given that African Americans from the South are exposed to stronger feelings of intolerance, it is not immediately intuitive whether they would be less sensitive or more sensitive than their northern counterparts. The results suggest, however, that African Americans from the South are more sensitive to racially intolerant attitudes. That said, African Americans from the North would need to receive a greater hourly wage supplement than African Americans from the South to compensate them for increased exposure to hate crimes.

A striking outcome is the divide among African Americans with respect to region after controlling for racial tolerance. Those originating in the North exhibit an extreme distaste for the South at the margin, which contrasts sharply with the extreme taste for the South displayed by African Americans originating in the South. Previous studies have missed this critical divide. In addition, studies that have attributed a negative coefficient on a South indicator to racial discrimination, have missed another key point. African Americans in the North would still prefer a city in the North after controlling for racial intolerance and distance. ${ }^{2}$

\section{Recent Developments and Migrant Characteristics}

The South's net loss of African Americans, for a century after the Civil War, finally subsided in the early 1970s, and the region has exhibited a net gain in African American population since that time (See Chart 2). Weiss and Williamson [1972] were the first to document any movement from the North to the South with micro data, using the 1967 Survey of Economic Opportunity (SEO). A modest 3.4 percent of SEO respondents born in the North moved to the South compared to 26.3 percent of respondents from the South heading North. McHugh [1987] illustrates the South's modest net gain of 14,000 African

\footnotetext{
2 "North" refers to areas outside the "South." "South" refers to states in which slavery was legal in 1860 unless otherwise noted. "City" and "metro area" are used interchangeably.
} 
Americans during the 1970-75 period. My tabulations of the latest available data show that 341,000 African Americans went North between 1995 and 2000, but African American gross migration to the South was nearly twice this magnitude at 665,000. In contrast, white gross migration to the South was 1.5 times greater than white gross migration to the North (See Table 6).

On a more detailed level of geography, I find that by the end of the 1990's most Southern states no longer lost African Americans on net, and several demonstrated sizeable gains (See Table 7). In addition to the narrowing of the racial wage gap in the South, this recent flow to the region may be explained by favorable employment conditions and housing prices (See Table 8).

Furthermore, my tabulations of the 2000 IPUMS show that African Americans in the North were more attracted to the South than any other race/ethnic group between 1995 and 2000. Among migrants starting in the North, 40 percent of African Americans chose a Southern city compared to 24 percent of Whites and Hispanics, and 20 percent of Asian Americans. ${ }^{3}$ Thus, this strong pull to the South was unique among African Americans, and surprising in light of the historical repression and high out-migration from the South documented above.

The magnitude of the inter-region migration in this period is impressive. Of 2.8 million total migrant households from the South, 0.9 million chose a metro area in the North. Of the 5.5 million migrant households in metro areas in the North, 1.5 million chose a metro area in the South as their destination.

Considering the migration flows for individual metropolitan areas. Table 7 showed that D.C. lost 35,000 African Americans on net, yet D.C. was the \#2 destination for African American migrants originating in the North and migrating to the South. The fact that almost 20 percent of all African American migrants to the South chose Atlanta

\footnotetext{
${ }^{3}$ I now restrict migrants to those starting in an identified metropolitan statistical area (MSA) and whose destination is an identified MSA. On the whole, $80 \%$ of African Americans lived in identified MSAs while $65 \%$ of whites live in these areas in 2000.
} 
is even more striking. Note that the cities with the most African Americans prior to the migration period are not necessarily the cities that attract the most African Americans. In fact, Memphis, New Orleans, and St. Louis do not make the Top 11 Southern city destinations for this group, though they have large African American population shares (See Table 9).

When considering all destination cities of African American migrants originating in the North, Atlanta remained a favorite. Southbound migration is not only a story about Atlanta, however. Of African American migrants from New York, Detroit, Chicago, Los Angeles, and Boston, the share that chose other Southern cities was 16, 8, 7, 7, and 6 percent, respectively (See Table 10).

A natural first question is how do these migrants from the North differ from those already in the South? Table 9 provides some answers. As would be expected, migrants are typically younger than nonmigrants. The differences in educational attainment are also expected but still striking nonetheless. Sixty-seven percent of African American migrants to the South received some type of higher education, compared to 47 percent of African American nonmigrants already in the South.

When comparing migrants to each other, however, it is clear that differences in their personal characteristics cannot explain different reactions to racism, as their characteristics are remarkably similar (See Table 11).

Previous studies have explained African Americans abandoning the South explicitly by the pull of economic opportunities in the North and implicitly by the push of racial discrimination, race-based violence, and social apartheid in the South. Given the demonstrated migration reversal, can those same reasons explain migration today?

\section{How does a Migrant Choose a City?}

From Sjaastad [1962] and Harris and Todaro [1970], the location choice of migrants has been modeled as the outcome of utility maximization. In these early studies, utility was 
composed of income or expected income. More recently, Borjas [1992] accounts for a random utility component specific to the individual to model interstate migration. He models the location decision as a comparison between the log of wage in various possible destinations. Thus, he essentially uses an additive log utility form, if we consider wage to be the only component of utility. Dahl [2002] suggests the utility function includes non-wage determinants of utility, including location amenities, and individual-specific deviations in tastes for these amenities. Dahl also assumes a linear additively separable form for the wage, non-wage, and random components of utility. Drawing on the studies above, I model utility as a function of personal characteristics, location-specific (dis)amenities, and an individual-specific idiosyncratic term:

$$
\mathcal{U}=f(w, \vec{x}, \vec{p}, \varepsilon)
$$

where $f$ is a linear function, $w$ is wage, $\vec{x}$ is a number of personal characteristics, $\vec{p}$ is composed of attributes specific to a location, and $\varepsilon$ is the individual idiosyncrasy.

A migrant chooses location $j$ over location $k$ when utility in $j$ is greater than utility in $k$ :

$$
\begin{gathered}
\mathcal{U}_{j}>\mathcal{U}_{k} \\
\Leftrightarrow f\left(w_{j}\right)+f(\vec{x})+f\left(\vec{p}_{j}\right)+\varepsilon_{j}>f\left(w_{k}\right)+f(\vec{x})+f\left(\vec{p}_{k}\right)+\varepsilon_{k} \\
\Leftrightarrow f\left(w_{j}\right)+f\left(\vec{p}_{j}\right)-f\left(w_{k}\right)-f\left(\vec{p}_{k}\right)>\varepsilon_{k}-\varepsilon_{j} .
\end{gathered}
$$

In this study, the variables of interest are in $\vec{p}$; racially motivated crimes and social attitudes about race are disamenities of a location. Controlling for racial wage disparities ensures that my racial intolerance measures do not capture the labor market costs of being African American. Thus, $\vec{p}$ also contains the city relative wage cost of being African American; otherwise stated, the relative rate of disreturn to wages of being African American is included as a location attribute. Relative returns to personal characteristics have already been used to explain migration patterns. In the spirit of Roy [1951], Borjas 
[1992] finds that the probability of moving to a state with higher returns to skill (measured by wage dispersion) increases with skill level. Dahl [2002] finds that individuals with more education do migrate to states with higher returns to education. Vigdor [2006] also considers regional racial wage disparities but tries to explain them by migration trends, which is the opposite causality. He concludes that the migration pattern reversal poorly explains the observed labor market developments.

\section{Hate Crime Endogeneity \& Quantifying Attitudes}

I obtain data on racial attitudes from the General Social Survey (GSS) for the years 1973 to 1993. I calculate a $\underline{r}$ acial $\underline{i}$ ntolerance $\underline{i}$ ndex (RiTI) for each metro area based on the answers of white respondents to questions about race after a costly decoding and matching procedure (See Data Appendix). I grouped these responses into two time periods, 19731982 and 1983-1993, to calculate a level of racial intolerance in each time period and also the growth in racial intolerance from the first period to the next ( $\Delta$ RiTI). The RiTI level is a composite of the percentage of white respondents who answered intolerantly to the following questions; intolerant answers are in italics:

- Would you yourself have any objection to sending your children to a school where half of the children are Negroes/Blacks/African- Americans? yes

- If your party nominated a Negro/Black/African-American for President, would you vote for him if he were qualified for the job? no

- Do you agree, disagree, or have no opinion on the following statement: White people have a right to keep Negroes/Blacks/African-Americans out of their neighborhoods if they want to, and Negroes/Blacks/African-Americans should respect that right. agree

- Do you think there should be laws against marriages between Negroes/Blacks/AfricanAmericans and whites? yes

- Do you agree, disagree, or have no opinion on the following statement: Negroes/Blacks/ African-Americans shouldn't push themselves where they're not wanted. agree 
I provide tabulations of responses for representative areas in Table 12. Though some of these questions appeal to outright bigotry and others to what some would call statistical discrimination, of sole importance here is: (1) whether migrants are averse to the presence of such attitudes and (2) what they believe the consequences of such attitudes may be. As Verdier and Zenou [2004] show, the presence of whites' negative racial beliefs can be detrimental to African Americans. Furthermore, I do not attempt to explain the change in attitudes documented in Table 12, but rather the migration choices that may depend on the trajectory of racial tolerance.

The Uniform Crime Reporting Program (UCRP) provides FBI data on hate crimes. The first measure of race-based violence against African Americans is the number of hate crimes committed against African Americans per African American resident, or the rate of hate crimes against African Americans. The rate of hate crimes is expected to capture a migrant's response to the real potential of being the victim of a hate crime. The total number of hate crimes against African Americans serves as the second measure. The level of hate crimes appeals to a more emotional, albeit no less valid reaction to the sheer scandal of such crimes.

I face an endogeneity problem using hate crimes against African Americans as a determinant of their migration. The arrival of African Americans may increase racial tension and spawn hate crimes against them. The consequence would be an upward bias in the estimated effect of anti-African American hate crimes. This motivates the need to instrument hate crimes against African Americans (as a determinant of their migration).

I instrument the rate of hate crimes against African Americans with the number of assaults on white police officers per African American resident. Assaults on white police officers cause the degradation of race relations in a number of ways. White police officers become more likely to racially profile and/or retaliate against African Americans. In addition, these actions send two signals to other members of the white community and other groups: (1) that is it more acceptable to mistreat African Americans because 
upholders of the law do it and (2) that offenders are less likely to face criminal punishment because law enforcement agents are also intolerant. These factors encourage hate crimes against African Americans.

I use total hate crimes against Jews as the instrument for total hate crimes against African Americans. Hate crimes against Jews and African Americans are typically perpetrated by the same groups.

The two instruments are strong predictors of the respective endogenous variables (See Table 13). Provided assaults on white police officers and hate crimes against Jews are not caused by African American migration, these are also valid instruments. Both these offenses are criminal and/or racially motivated. To check the validity, I will show that African American migrants are less likely to commit a crime and less racially intolerant than African American nonmigrants.

The most commonly cited socioeconomic determinants of criminal behavior are unemployment, education level (because it affects expected lifetime earnings in the legal sector), and income inequality. Table 14 shows that African American migrants are less likely to commit crimes than African American nonmigrants in all these respects. They have lower unemployment rates, higher educational attainment, and are better off in the income distribution.

Furthermore, African American migrants are less racially intolerant (See Table 15). They have less mistrust of white people, are more welcoming of white people, and have less separatist views than African American nonmigrants. African American migrants also have warmer feelings towards Jews than African American nonmigrants. Thus, African American migrants to an area should not cause either instrument. ${ }^{4}$

\footnotetext{
${ }^{4}$ One might entertain that Afr. Am. migration adversely affects native groups and these groups may react violently against any group including white police officers and Jews. Another hypothetical situation is one in which white police officers and Jews provoke assaults because of their feelings about Afr. Am. migration. Both these scenarios would mean, however, that African American migration were positively correlated with the instruments, which implies an upward bias in the coefficient. Thus, if this
} 


\section{Estimating the Importance of Racism}

\section{Wages}

I assume an individual's wage is composed of a "base" wage $(\omega)$ invariant to location, a location-specific part $(\zeta)$, and a bundle of unobservable qualities $(\nu)$. Using the previous assumptions, the following expresses an individual $i$ 's log wage in a city $c$ :

$$
\text { wage }_{i c}=\omega_{i}+\zeta_{i c}+\nu_{i}
$$

I now assume a structural form for the determination of wages in each city, which is a function of $\widetilde{x}=\{$ race, gender, education, marital status, experience, experience squared $\}$ :

$$
\ln \text { wage }_{c}=\gamma_{1 c} \exp +\gamma_{2 c} \text { sex }+\gamma_{3 c} e d u c+\gamma_{4 c} e p^{2}+\gamma_{5 c} \text { race }+\gamma_{6 c} \text { married }+\mu
$$

Next, I argue that $\left\{\gamma_{1 c}, \gamma_{2 c}, \gamma_{3 c}, \gamma_{4 c}, \gamma_{5 c}, \gamma_{6 c}\right\}$ are all actually composed of a location invariant part $\left(\gamma_{s}\right)$ and a location specific part $\left(\eta_{s c}\right)$, so that for an individual in a given city:

$$
\begin{aligned}
\ln \text { wage }_{i c}= & \left(\gamma_{1}+\eta_{1 c}\right) \exp _{i}+\left(\gamma_{2}+\eta_{2 c}\right) \operatorname{sex}_{i}+\left(\gamma_{3}+\eta_{3 c}\right) \text { educ } i+ \\
& \left(\gamma_{4}+\eta_{4 c}\right) \exp _{i}^{2}+\left(\gamma_{5}+\eta_{5 c}\right) \text { race }_{i}+\left(\gamma_{6}+\eta_{6 c}\right) \text { married }_{i}+\mu_{i}
\end{aligned}
$$

Otherwise stated, $\left\{\eta_{1 c}, \eta_{2 c}, \eta_{3 c}, \eta_{4 c}, \eta_{5 c}, \eta_{6 c}\right\}\left(=\vec{\eta}_{c}\right)$ are the relative prices for these personal characteristics in city $c^{5}$. Distributing in (3) gives:

$$
\ln \operatorname{wage}_{i c}=\vec{\gamma} \widetilde{x}_{i}+\vec{\eta}_{c} \widetilde{x}_{i}+\mu_{i}
$$

endogeneity truly existed the negative coefficient $(\widehat{\beta})$ I obtain for hate crimes would be more positive than the true coefficient $\left(\beta_{0}\right)$. Otherwise stated, correcting the possible endogeneity would only result in a more negative coefficient and improve the results: $\beta_{0}<\widehat{\beta}<0$.

${ }^{5}$ For a given city $c$, the vector of relative prices for all wage determinants is $\vec{\eta}_{c}$. For a given wage determinant $s$, the vector of relative prices for all cities is $\vec{\eta}_{s}$. 
when defining $\vec{\gamma}=\left\{\gamma_{1}, \gamma_{2}, \gamma_{3}, \gamma_{4}, \gamma_{5}, \gamma_{6}\right\}$ and recalling the definition of $\widetilde{x}$.

Clearly, $\vec{\gamma} \widetilde{x}_{i}$ is a part of the wage that does not vary with location and $\vec{\eta}_{c} \widetilde{x}_{i}$ are the location specific returns. Thus, the former is simply $\omega_{i}$ and the latter is $\zeta_{i c}$ from (1). I calculate $\vec{\eta}_{c}$ - the relative rates of (dis)return to wages of race, gender, education, marriage, experience, and experience squared - with wage equations that include metro area indicators and metro area indicators interacted with the relevant wage determinant (See Footnote 6 ). Finally, let's call $\vec{\eta}_{c} \widetilde{x}_{i}$ the city-relative wage for individual $i$ and define $\varpi_{i c}=\vec{\eta}_{c} \widetilde{x}_{i}$

\section{Utility}

Utility in a city is a function of an individual's city-relative wage $\left(\varpi_{i c}\right)$, amenities and disamenities that cities offer, and distance from the city of origin $\left(d_{i c}\right)$.

In this study, the variables of interest are in $\vec{p}$ the vector of $h$ city specific amenities; hate crime activity, level of racial intolerance (RiTI), and progress in racial tolerance $(\Delta \mathrm{RiTI})$ are attributes of a city. Again, I am controlling for racial wage disparities. An element of $\vec{p}$ is the city relative wage penalty for being African American. ${ }^{6}$

Other area characteristic controls are the unemployment rate, employment growth, home price index, general crimes (exclusive of hate crimes), location in the South, African American population share, segregation, total population, population growth, and weather. See the Data Appendix for sources, methods, and summary statistics.

Thus, an individual $i$ 's utility in city $c$ is

$$
\mathcal{U}_{i c}=\alpha \varpi_{i c}+\vec{\beta} \vec{p}_{c}+\delta d_{i c}+\varepsilon_{i c}
$$

${ }^{6}$ The vector of city relative (dis)returns to a wage determinant $s$ is the coefficient vector $\vec{\eta}_{s}$ in the following:

$$
\ln (\text { wage })=\vec{\alpha} \widetilde{x}_{-s}+\vec{\lambda}_{c} \vec{D}_{c}+\vec{\eta}_{s} \vec{D}_{c} s
$$

where $\widetilde{x}_{-s}$ is a vector of wage determinants save $s$ and $\vec{D}_{c}$ is a vector of city indicators. 
Migrants compare utility in all possible destinations, and choose the city $k$ that offers them the greatest utility. Thus, a given individual's destination choice is reached by considering utility returns to city-specific amenities $\left(\overrightarrow{p_{c}}\right)$, the utility from city-specific wage returns to individual characteristics $\left(\varpi_{i c}\right)$, distance $\left(d_{i c}\right)$ and utility returns from an unobservable $\left(\varepsilon_{i c}\right)$. Because $\varpi_{i c}$ and $d_{i c}$ depend only on $c$ for a given individual $i$, I represent it as a location characteristic from the point-of-view of the individual and $\alpha$ and $\delta$ are consequently elements of $\vec{\beta}$.

To estimate $\vec{\beta}$, I model the probability that the observed chosen location $\mathcal{L}$ is city $c$ as a function of amenities of the alternatives, using the McFadden conditional logit specification and assuming the $\varepsilon_{i c}$ are i.i.d. $\sim$ Weibull. Formally,

$$
\operatorname{Prob}(\mathcal{L}=c)=\frac{e^{\vec{\beta} \vec{p}_{c}}}{\Sigma_{c} e^{\vec{\beta} \vec{p}_{c}}}
$$

I choose a control function approach to deal with the hate crime endogeneity. In standard notation,

$$
y=\beta p_{1}+\varepsilon, \mathbb{E}\left(p_{1} \varepsilon\right) \neq 0,
$$

where $y$ represents migration and $p_{1}$ stands for hate crimes against African Americans. I assume that the above proposed instruments, $z$, satisfy $\mathbb{E}(z \varepsilon)=0$.

I can then represent the endogenous variable as

$$
p_{1}=\theta z+v,
$$

where $v$ is the part of $p_{1}$ that may be caused by $y$. I control for the endogeneity by introducing a predicted $v$ as an element of $\vec{p}$.

Equation (6) is estimated separately for white and African American migrants, each by region of origination (South or North). ${ }^{7}$

\footnotetext{
${ }^{7}$ For the purpose of symmetry the identical specification is used for both whites and African Americans. This causes an endogeneity problem for whites in one set of results because the instrument for total black
} 


\section{Racial Intolerance is a Significant Deterrent}

The first set of results (IV1) relies on per capita hate crimes against African Americans as the relevant representation of hate crime activity (See Table 1 in this section). The instrument for this endogenous variable is attacks on white police officers per African American resident. The effect of per capita hate crimes is quite large and significant for African Americans originating in the North, and has a smaller significant impact on those from the South. If the hate crime rate rises by one standard deviation in the average city, the predicted probability that an African American from the North would choose the average city decreases by a factor of 6 . This probability would also decrease for an African American from the South, but only by a factor of 1.3 . Hate crimes are a greater deterrent to migrants from the North than to their Southern counterparts. Still, the effect on African Americans from the North is much larger than that on whites from the North. Furthermore, though the importance of hate crimes for African Americans from the South is small in comparison to migrants from the North, the effect is even smaller for whites from the South.

Recall that the potential endogeneity problem would have resulted in an upward bias. Indeed, without the endogeneity correction, the coefficient on per capita hate crimes is closer to 0 (more positive) for all groups. The interpretation of these biased coefficients would lead to a much smaller perceived impact of hate crimes. For example, if the hate crime rate were to rise by one standard deviation in the average city, the perceived probability that an African American from the North would choose the average city would decrease by a factor of just 1.6 (compared to the endogeneity-corrected factor of 6 ).

That said, the level of racially intolerant attitudes significantly reduced the probability hate crimes is total hate crimes against Jews. White migration includes Jews and may increase hate crimes against these members of the white community. Thus, the results for whites should be interpreted cautiously. In addition, the IPUMS estimations for white migrants are based on a random sample of the total number of white migrants because of computing constraints. Finally, the results are generated assuming Independence of Irrelevant Alternatives. 
of choosing a city for a given individual from all race groups and regions of origin. Given that African Americans in the South are exposed to stronger feelings of intolerance, it is not immediately intuitive whether they would be less sensitive or more sensitive. The level of racially intolerant attitudes has a larger impact on African Americans originating in the South than on their Northern counterparts. If negative attitudes toward African Americans in the average city increases by one standard deviation, the probability of an African American from the South choosing that city declines by a factor of 1.8 compared to a factor of 1.3 for an African American from the North.

Recall that a negative growth rate of intolerant attitudes reflects progress; the results show that a lack of progress in the racial attitudes of whites decreased the probability of choosing a city for both groups of African Americans. The magnitude of the effect is much smaller for whites. If the lack of progress in attitudes were to increase by one standard deviation in the average city, the probability that both groups of African Americans would choose the average city decreases by a factor of 1.3 . Such a change in the progress of attitudes hardly impacts the probability of a white migrant choosing the average city. From this specification, it is clear that relatively low racial tolerance reduced a city's attractiveness for African American migrants.

Now I consider the robustness of the representation of hate crimes in $I V 1$. In place of per capita hate crimes, I use the level of hate crimes against African Americans (IV2). As mentioned earlier, this representation appeals to the effect that outrage from hate crimes may have. The potential endogeneity problem remains, and I use the level of hate crimes against Jews as an instrument (see Table 2 in this section). African Americans from the North showed a significant distaste for cities with higher levels of hate crimes. African Americans from the South also displayed a negative reaction to the level of hate crimes, but a stronger one. Though whites from the North exhibited a small negative response to per capita hate crimes, the coefficient is now positive though very small (See Footnote 6). As in the previous estimation, the magnitude of the effect of hate crimes is larger for African 
Americans than whites. Again, without the endogeneity correction, the coefficients on hate crimes are consistent with an upward bias. They are more positive for all groups. The endogeneity correction results in the coefficients for African Americans being at least twice as negative. Using total hate crimes against African Americans does not change the impact of racial attitudes qualitatively for any group. Both groups of African Americans remain significantly deterred by the level of racial intolerance. In addition, this specification supports the finding that African Americans were more concerned with the trajectory of negative attitudes than whites.

I perform an additional robustness check for the results in $I V 1$ by changing the migrant data source to the 2000 CPS (IV3). ${ }^{8}$ The results largely support the findings in $I V 1$, yet the small sample sizes for African Americans prevent many significant outcomes (See Table 3 in this section). That said, the level of racially intolerant attitudes remains a significant deterrent to African Americans from both regions. The hate crime rate has a large impact on the probability of African Americans from the North choosing a city, but the effect is not significant. The effect of hate crimes is also negative for African Americans from the South but much smaller. The lack of progress in racial attitudes remains a deterrent to migration, but fails to achieve significance for either group.

As a final robustness check, I pool the 5 cross-sections of CPS data from 1996 to 2000 in IV 4. Clearly this approach will not yield coefficients comparable to the previous ones, but it provides some additional support for the importance of racism to migrants and allows a greater number of observations than $I V$ 3. The level of racially intolerant attitudes is again a deterrent for all groups. Less progress in these attitudes still has the greatest impact on African Americans, however. Similar to IV3, hate crimes do not achieve significance for African Americans from either region.

\footnotetext{
${ }^{8}$ The migration period in the CPS data is shorter at 1 year, but does overlap with that used in $I V 1$. The CPS does not provide the metro area of origin and so migrants are identified as those who made interstate moves although their destination choice is still a metro area. In some cases an interstate move does not imply changing metro areas. An additional consequence is that the distance control is absent.
} 
In sum, African Americans are significantly deterred by high levels of racially intolerant attitudes, lack of progress in racial tolerance, the probability of being a hate crime victim, and by the total level of hate crimes against their group. Furthermore, it appears that all groups dislike racial intolerance, but that African Americans are particularly sensitive to hate crimes and the lack of progress in attitudes.

Recall some of the descriptive statistics mentioned earlier and consider their irony in the context of these results. The fact that over 1 million African Americans (20\%) left the South in the 1940s clearly indicates a distaste for the region. Yet, just 2-3 generations later, the fact that African Americans from the South show a strikingly strong taste for cities in the South is remarkable. Furthermore, they show a greater attachment to the region than whites in all specifications. Controlling for racial climate strongly suggests that for the century after the Civil War, African Americans in the South were fleeing racial intolerance and not the South per se, a distinction other studies have failed to make.

Also surprising is the distaste for the South on the part of African Americans from the North. First, from the raw tabulations above they do not appear significantly unlikely to move South (40\%). Secondly, they were more likely than any other race group to do so. Thus, studies that have attributed a negative coefficient on a South indicator to racial intolerance have missed this key point. African Americans from the North would still prefer a location in the North after controlling for racial intolerance.

Finally, recall that 6-7 generations ago, virtually all African Americans lived in the South! The two groups are now sharply divided in their affection for the region. Previous studies that have grouped African Americans from both regions have missed this divide. 
Table 1: IV1 Conditional Logit Fixed-Effects Model of Destination Choice (IPUMS)

\begin{tabular}{|c|c|c|c|c|c|c|c|c|}
\hline \multicolumn{9}{|c|}{ Dependent Variable: Indicator that Migrant $i$ Chose City $c$} \\
\hline & \multicolumn{4}{|c|}{ African Americans } & \multicolumn{4}{|c|}{ Whites } \\
\hline & \multicolumn{2}{|c|}{$\begin{array}{c}\text { Migrants of } \\
\text { Northern Origin }\end{array}$} & \multicolumn{2}{|c|}{$\begin{array}{c}\text { Migrants of } \\
\text { Southern Origin }\end{array}$} & \multicolumn{2}{|c|}{$\begin{array}{c}\text { Migrants of } \\
\text { Northern Origin }\end{array}$} & \multicolumn{2}{|c|}{$\begin{array}{c}\text { Migrants of } \\
\text { Southern Origin }\end{array}$} \\
\hline & Coeff. & S.E. & Coeff. & S.E. & Coeff. & S.E. & Coeff. & S.E. \\
\hline 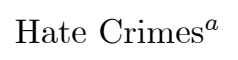 & $* * *-0.0551$ & 0.0062 & $* *-0.0081$ & 0.0028 & $* * *-0.0131$ & 0.0024 & $* *-0.0059$ & 0.0024 \\
\hline $\operatorname{RiTI}^{b}$ & $* * *-0.0284$ & 0.0029 & $* * *-0.0628$ & 0.0030 & $* * *-0.0621$ & 0.0031 & $* * *-0.0494$ & 0.0026 \\
\hline$\Delta \mathrm{RiTI}$ & $* * *-0.0147$ & 0.0009 & $* * *-0.0160$ & 0.0011 & $* * 0.0015$ & 0.0008 & $* * *-0.0039$ & 0.0009 \\
\hline South Dummy & $* * *-0.2266$ & 0.0368 & $* * * 1.4504$ & 0.0496 & $* * *-0.6141$ & 0.0376 & $* * * 0.5544$ & 0.0386 \\
\hline Control Fct. ${ }^{c}$ & $* * * 0.0517$ & 0.0071 & 0.0037 & 0.003 & $* * * 0.0136$ & 0.0026 & 0.0046 & 0.0026 \\
\hline Unique Obs. & 10070 & & 8275 & & 9760 & & 8231 & \\
\hline Pseudo $\mathrm{R}^{2}$ & .18 & & .29 & & .15 & & .15 & \\
\hline
\end{tabular}

Control Variables: Per Capita Non-Hate Crimes, African American Population Share, Segregation,

Unemployment Rate, Employment Growth, Population Growth, Population,

House Price Index, Distance from Origin City, Rate of Disreturn to Wages of Being Afr. American,

City Relative Wage Returns to Characteristics, Average Range of Temperatures, Average Temperature

${ }^{a}$ Anti-Afr. Am. hate crimes per Afr. Am. with assaults on white police officers as instrument.

${ }^{b}$ Level of Racially Intolerant Attitudes

${ }^{c}$ Predicted residuals from first stage regression of endogenous variable on instrument.

Robust standard errors. *** denotes significance at the $1 \%$ level, ** $5 \%$ level. 
Table 2: IV2 Conditional Logit Fixed-Effects Model of Destination Choice (IPUMS)

\begin{tabular}{|c|c|c|c|c|c|c|c|c|}
\hline \multicolumn{9}{|c|}{ Dependent Variable: Indicator that Migrant $i$ Chose City $c$} \\
\hline & \multicolumn{4}{|c|}{ African Americans } & \multicolumn{4}{|c|}{ Whites } \\
\hline & \multicolumn{2}{|c|}{$\begin{array}{l}\text { Migrants of } \\
\text { Northern Origin }\end{array}$} & \multicolumn{2}{|c|}{$\begin{array}{c}\text { Migrants of } \\
\text { Southern Origin }\end{array}$} & \multicolumn{2}{|c|}{$\begin{array}{c}\text { Migrants of } \\
\text { Northern Origin }\end{array}$} & \multicolumn{2}{|c|}{$\begin{array}{c}\text { Migrants of } \\
\text { Southern Origin }\end{array}$} \\
\hline & Coeff. & S.E. & Coeff. & S.E. & Coeff. & S.E. & Coeff. & S.E. \\
\hline 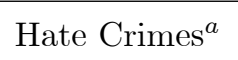 & $* * *-0.0135$ & 0.0007 & $* * *-0.0376$ & 0.0012 & $* * 0.0058$ & 0.0006 & $* * *-0.0083$ & 0.0011 \\
\hline $\operatorname{RiTI}^{b}$ & $* * *-0.0335$ & 0.0029 & $* * *-0.0452$ & 0.0028 & $* * *-0.0617$ & 0.0033 & $* * *-0.0350$ & 0.0029 \\
\hline$\Delta \mathrm{RiTI}$ & $* * *-0.0138$ & 0.0009 & $* * *-0.0113$ & 0.0009 & $* * * 0.0036$ & 0.0009 & $* * *-0.0052$ & 0.0009 \\
\hline South Dummy & $* * *-0.2988$ & 0.0386 & $* * * 1.3953$ & 0.0610 & $* * *-0.5263$ & 0.0392 & $* * * 0.5104$ & 0.0412 \\
\hline Control Fct. ${ }^{c}$ & $* * * 0.0160$ & 0.0008 & $* * * 0.0443$ & 0.0012 & 0.0001 & 0.0007 & $* * * 0.0136$ & 0.0012 \\
\hline Unique Obs. & 10070 & & 8275 & & 9760 & & 8231 & \\
\hline Pseudo $\mathrm{R}^{2}$ & .17 & & .32 & & .15 & & .14 & \\
\hline
\end{tabular}

Control Variables: Per Capita Non-Hate Crimes, African American Population Share, Segregation,

Unemployment Rate, Employment Growth, Population Growth, Population,

House Price Index, Distance from Origin City, Rate of Disreturn to Wages of Being Afr. American,

City Relative Wage Returns to Characteristics, Average Range of Temperatures, Average Temperature

$a$ Total Anti-Afr. Am. hate crimes with total Anti-Jew hate crimes as instrument.

${ }^{b}$ Level of Racially Intolerant Attitudes

${ }^{c}$ Predicted residuals from first stage regression of endogenous variable on instrument.

Robust standard errors. *** denotes significance at the $1 \%$ level, ** $5 \%$ level. 
Table 3: IV3 Conditional Logit Fixed-Effects Model of Destination Choice (CPS)

\begin{tabular}{|c|c|c|c|c|c|c|c|c|}
\hline \multicolumn{9}{|c|}{ Dependent Variable: Indicator that Migrant $i$ Chose City $c$} \\
\hline & \multicolumn{4}{|c|}{ African Americans } & \multicolumn{4}{|c|}{ Whites } \\
\hline & \multicolumn{2}{|c|}{$\begin{array}{c}\text { Migrants of } \\
\text { Northern Origin }\end{array}$} & \multicolumn{2}{|c|}{$\begin{array}{c}\text { Migrants of } \\
\text { Southern Origin }\end{array}$} & \multicolumn{2}{|c|}{$\begin{array}{c}\text { Migrants of } \\
\text { Northern Origin }\end{array}$} & \multicolumn{2}{|c|}{$\begin{array}{c}\text { Migrants of } \\
\text { Southern Origin }\end{array}$} \\
\hline & Coeff. & S.E. & Coeff. & S.E. & Coeff. & S.E. & Coeff. & S.E. \\
\hline Hate Crimes $^{a}$ & -0.1362 & 0.1431 & -0.0289 & 0.1789 & 0.0134 & 0.0633 & $* *-0.1682$ & 0.0779 \\
\hline $\operatorname{RiTI}^{b}$ & $* *-0.0742$ & 0.0392 & $* * *-0.0778$ & 0.0299 & $* * *-0.0745$ & 0.0156 & $* * *-0.0469$ & 0.0158 \\
\hline$\Delta \mathrm{RiTI}$ & -0.0020 & 0.0094 & 0.0058 & 0.0114 & 0.0054 & 0.0033 & $* * *-0.0126$ & 0.0048 \\
\hline South Dummy & $* *-1.1729$ & 0.5100 & $* * * 2.5473$ & 0.6380 & $* * *-0.9208$ & 0.2303 & $* * * 2.0038$ & 0.2800 \\
\hline Control Fct. ${ }^{c}$ & 0.0128 & 0.0085 & 0.0228 & 0.0126 & 0.0006 & 0.0033 & 0.0028 & 0.0057 \\
\hline Pseudo R ${ }^{2}$ & .18 & & .29 & & .12 & & .21 & \\
\hline Unique Obs. & 76 & & 61 & & 486 & & 280 & \\
\hline
\end{tabular}

Control Variables: Per Capita Non-hate Crimes, African American Population Share, Segregation,

Unemployment Rate, Employment Growth, Population Growth, Population,

House Price Index, Distance from Origin City, Rate of Disreturn to Wages of Being Afr. American,

City Relative Wage Returns to Characteristics, Average Range of Temperatures, Average Temperature

${ }^{a}$ Anti-Afr. Am. hate crimes per Afr. Am. with assaults on white police officers as instrument.

${ }^{b}$ Level of Racially Intolerant Attitudes

${ }^{c}$ Predicted residuals from first stage regression of endogenous variable on instrument.

Robust standard errors. *** denotes significance at the $1 \%$ level, ** $5 \%$ level. 
Table 4: IV4 Conditional Logit Fixed-Effects Model of Destination Choice (Pooled CPS)

\begin{tabular}{|c|c|c|c|c|c|c|c|c|}
\hline \multicolumn{9}{|c|}{ Dependent Variable: Indicator that Migrant $i$ Chose City $c$} \\
\hline & \multicolumn{4}{|c|}{ African Americans } & \multicolumn{4}{|c|}{ Whites } \\
\hline & \multicolumn{2}{|c|}{$\begin{array}{c}\text { Migrants of } \\
\text { Northern Origin }\end{array}$} & \multicolumn{2}{|c|}{$\begin{array}{c}\text { Migrants of } \\
\text { Southern Origin }\end{array}$} & \multicolumn{2}{|c|}{$\begin{array}{l}\text { Migrants of } \\
\text { Northern Origin }\end{array}$} & \multicolumn{2}{|c|}{$\begin{array}{c}\text { Migrants of } \\
\text { Southern Origin }\end{array}$} \\
\hline & Coeff. & S.E. & Coeff. & S.E. & Coeff. & S.E. & Coeff. & S.E. \\
\hline 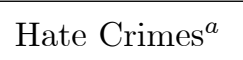 & 0.0053 & 0.0684 & -0.0545 & 0.0769 & $* * 0.0629$ & 0.0302 & $* *-0.1290$ & 0.0386 \\
\hline $\operatorname{RiTI}^{b}$ & $* *-0.0416$ & 0.0192 & $* * *-0.0728$ & 0.0160 & $* * *-0.0757$ & 0.0076 & $* * *-0.0320$ & 0.0068 \\
\hline$\Delta \mathrm{RiTI}$ & -0.0065 & 0.0046 & -0.0050 & 0.0047 & 0.0008 & 0.0017 & 0.0001 & 0.0020 \\
\hline South Dummy & $* * *-1.3110$ & 0.2630 & $* * * 2.6642$ & 0.2685 & $* * *-1.0259$ & 0.0942 & $* * * 1.6424$ & 0.1225 \\
\hline Control Fct. ${ }^{c}$ & 0.0015 & 0.0039 & 0.0092 & 0.0059 & -0.0013 & 0.0012 & 0.0054 & 0.0042 \\
\hline Pseudo $\mathrm{R}^{2}$ & .18 & & .29 & & .10 & & .17 & \\
\hline Unique Obs. & 294 & & 320 & & 2180 & & 1277 & \\
\hline
\end{tabular}

Control Variables: Per Capita Non-hate Crimes, African American Population Share, Segregation,

Unemployment Rate, Employment Growth, Population Growth, Population,

House Price Index, Distance from Origin City, Rate of Disreturn to Wages of Being Afr. American,

City Relative Wage Returns to Characteristics, Average Range of Temperatures, Average Temperature

${ }^{a}$ Anti-Afr. Am. hate crimes per Afr. Am. with assaults on white police officers as instrument.

${ }^{b}$ Level of Racially Intolerant Attitudes

${ }^{c}$ Predicted residuals from first stage regression of endogenous variable on instrument.

Robust standard errors. *** denotes significance at the $1 \%$ level, ** $5 \%$ level. 


\section{Conclusion \& Implications}

The results show that African Americans in the North and South are significantly deterred by per capita hate crime activity, the level of hate crimes, racially intolerant attitudes held by whites, and by the lack of progress in whites' attitudes about race-all regardless of the region in which a city is located. In addition, African Americans would need to be paid more than whites to be compensated for an increase in anti-African American per capita hate crimes.

Also striking is the divide among African Americans with respect to region. Those from the North exhibit a marked distaste for the South at the margin, which contrasts sharply with the extreme taste for the South displayed by African Americans from the South. Before this study, the divide was undocumented.

The potential implications of these findings are numerous. As mentioned earlier, the fact that African Americans are moving to the South on net where wage equality for them has increased will have consequences for the racial wage gap in the North and the South. If the migration behavior sparked by dispersed wage returns to race is similar to that provoked by dispersed returns to skill (Borjas [1987, 1992]), the racial wage gap in the North could converge past that of the South.

Furthermore, it is possible that the relatively intolerant attitudes in the South are dampening the recent net migration of African Americans into the South. Over time, when the racial attitudes of Southerners converged to attitudes in the North, more African Americans were in the South (See Chart 3). Conversely, when the attitudes of Southerners towards African Americans diverged from the attitudes of Northerners, a smaller share of African Americans was in the South. This is not necessarily causal, but it is consistent with the results presented above; I have shown that cities in the South still display higher levels of negative attitudes and that these attitudes reduce African American migration to a city. Thus the relatively higher intolerance in the South may be slowing the spatial redistribution of African Americans to the South. 


\section{References}

1. Blundell, R. and Powell J. "Endogeneity in Semiparametric Binary Response Models." The Review of Economic Studies. 2004. 71:3. 581-613.

2. Blundell, R. and Powell J. "Endogeneity in Nonparametric and Semiparametric Regression Models." Advances in Economics and Econometrics.eds. Dewatripont, M., Hansen, L., and Turnsovsky, S.J. Cambridge University Press. 2003. 312-357.

3. Borjas, George J. "Ethnicity, Neighborhoods, and Human-Capital Externalities." The American Economic Review. 1995. 85:3. 365-390.

4. Borjas, George J. "Self-Selection and the Earnings of Immigrants." The American Economic Review. 1987. 77:4. 531-553.

5. Borjas, George J., Bronars, Stephen G., and Trejo, Stephen J. "Self-Selection and Internal Migration in the United States." Journal of Urban Economics. 1992. 32. 159-185.

6. Bowles, Samuel. "Migration as Investment: Empirical Tests of the Human Investment Approach to Geographical Mobility." The Review of Economics and Statistics. 1970. 52:4. 356-362.

7. Collins, William J. "When the Tide Turned: Immigration and the Delay of the Great Black Migration." The Journal of Economic History. 1997. 57:3.607-632.

8. Dahl, Gordon B. "Mobility and the Return to Education: Testing a Roy Model with Multiple Markets." Econometrica. 2002. 70:6. 2367-2420.

9. Greenwood, Michael J. "Research on Internal Migration in the United States: A Survey." The Journal of Economic Literature. 1975. 397-433.

10. Harris, J.R. and Todaro, M.P. "Migration, Unemployment, and Development: A Two-Sector Analysis." American Economic Review. 1970. 60. 126-42.

11. Heckman, James J. "Sample Selection Bias as a Specification Error." Econometrica. 47. 153-161.

12. Heckman, James J. "The Central Role of the South in Accounting for the Economic Progress of Black Americans." The American Economic Review. 1990. 80:2. 242-246.

13. Lee, Seong Woo and Roseman, Curtis C. "Migration Determinants and Employment Consequences of White and Black Families, 1985-1990." Economic Geography. 1999. 75:2. 109-133.

14. McFadden, Daniel. "Conditional logit analysis of qualitative choice behavior", in Frontiers in Econometrics,(P. Zarembka, Ed.), Academic Press, New York. 1973.

15. McHugh, Kevin E. "Black Migration Reversal in the United States." Geographical Review. 1987. 77:2. 171-182. 
16. Nakosteen, R.A. and Zimmer, M. "Migration and Income: The Question of Self-Selection." Southern Economic Journal. 1980. 46:3. 840-851.

17. Navratil, Frank J. and Doyle, James J. "The Socioeconomic Determinants of Migration and the Level of Aggregation." Southern Economic Journal. 1977. 43:4. 1547-1559.

18. Roy, A.D. "Some Thoughts on the Distribution of Earnings." Oxford Economic Papers. 1951. 3. $135-146$.

19. Ruggles, Steven, Matthew Sobek, Trent Alexander, Catherine A. Fitch, Ronald Goeken, Patricia Kelly Hall, Miriam King, and Chad Ronnander. Integrated Public Use Microdata Series: Version 4.0 [Machine-readable database]. Minneapolis, MN: Minnesota Population Center [producer and distributor], 2008.

20. Tolnay, S.E. and Beck, E.M. "Racial Violence and Black Migration in the American South, 1910 to 1930." American Sociological Review. 1992. 57. 103-117.

21. Schlottmann, Alan M. and Herzog, Jr. Henry W. "Employment Status and the Decision to Migrate." The Review of Economics and Statistics. 1981. 63:4. 590-598.

22. Sjaastad, L.A. "The Costs and Returns of Human Migration." Journal of Political Economy. 1962. 70. 80-93.

23. U.S. Dept. of Justice, Federal Bureau of Investigation. UNIFORM CRIME REPORTING PROGRAM DATA [UNITED STATES]: HATE CRIME DATA, 1996 [Computer file]. Compiled by the U.S. Dept. of Justice, Federal Bureau of Investigation. ICPSR ed. Ann Arbor, MI: Inter-university Consortium for Political and Social Research [producer and distributor], 2000.

24. U.S. Dept. of Justice, Federal Bureau of Investigation. UNIFORM CRIME REPORTING PROGRAM DATA: [UNITED STATES], 1975-1997 [Computer file]. Compiled by the U.S. Dept. of Justice, Federal Bureau of Investigation. ICPSR09028-v5. Ann Arbor, MI: Inter-university Consortium for Political and Social Research [producer and distributor], 2005-09-30.

25. Verdier, Thierry and Zenou, Yves. "Racial Beliefs, Location, and The Causes Of Crime." International Economic Review. 2004. 45:3. 731-760.

26. Vigdor, Jacob L. "The New Promised Land: Black-White Convergence in the American South, 1960-2000." NBER Working Paper Series.

27. Vigdor, Jacob L. "The Pursuit of Opportunity: Explaining Selective Black Migration." Journal of Urban Economics. 2002. 51. 391-417.

28. Weiss, Leonard and Williamson, Jeffrey G. "Black Education, Earnings, and Interregional Migration: Some New Evidence." The American Economic Review. 1972. 372-383.25. 


\section{Charts, Figures, \& Tables}

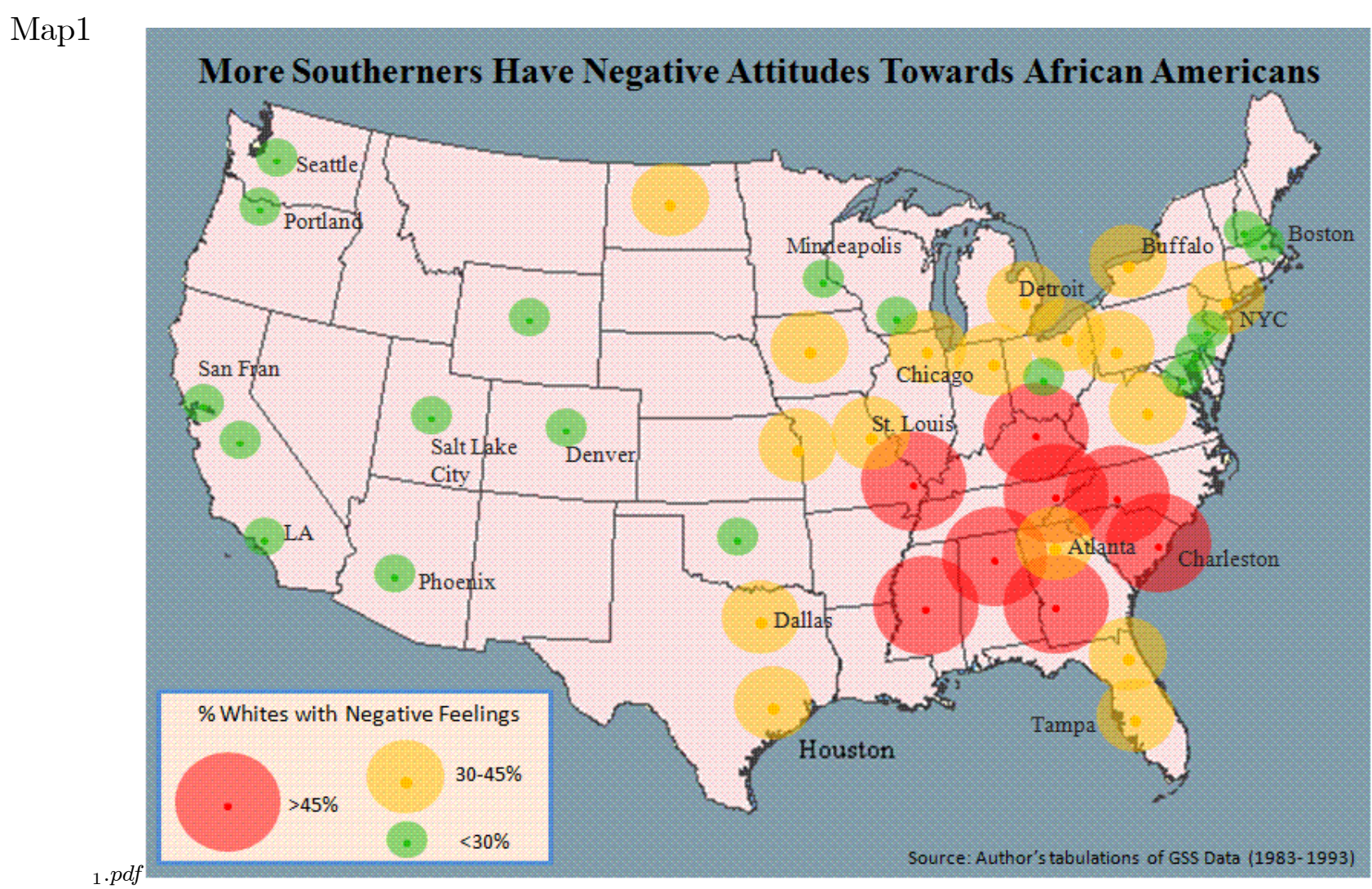




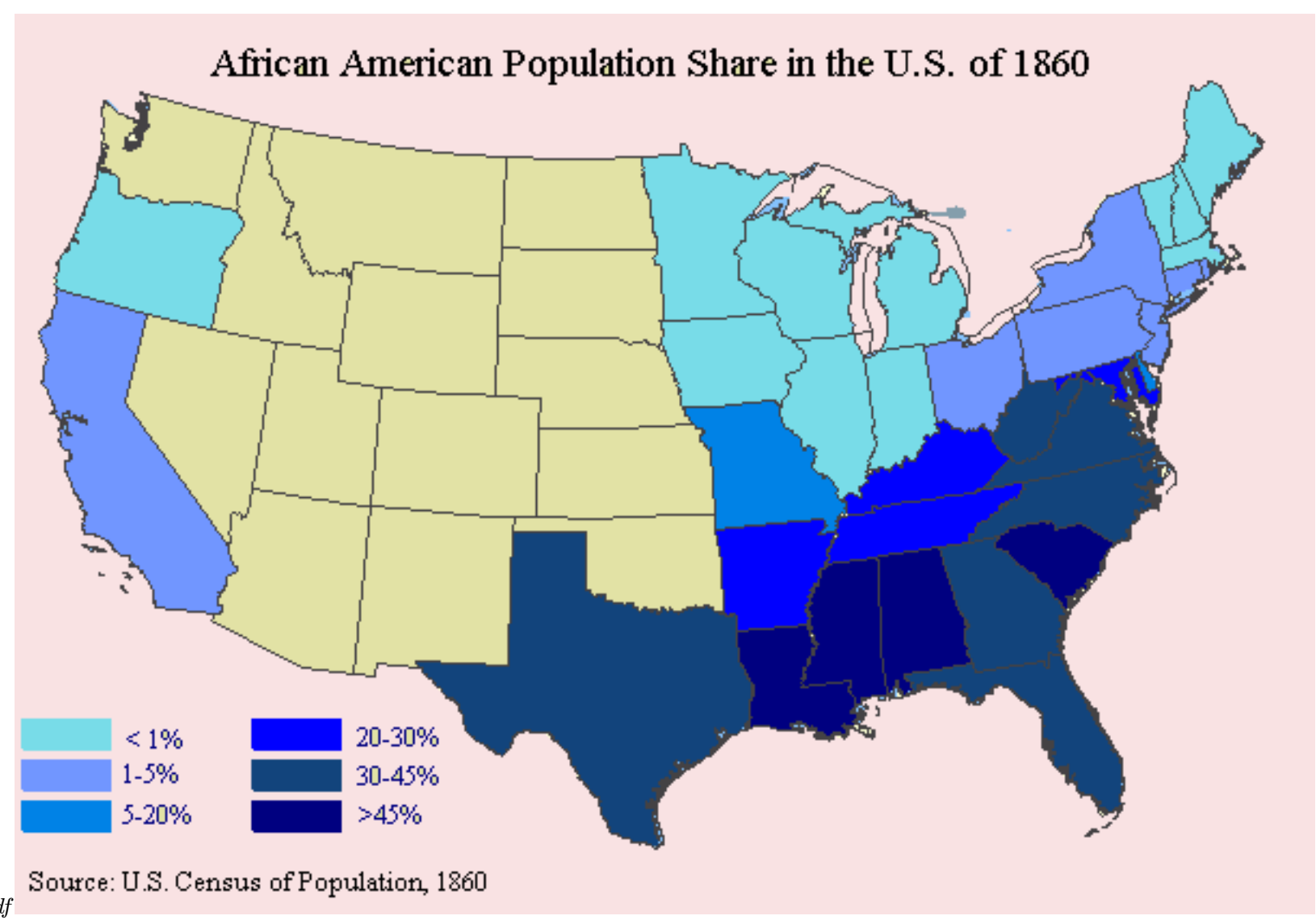

Map 2 


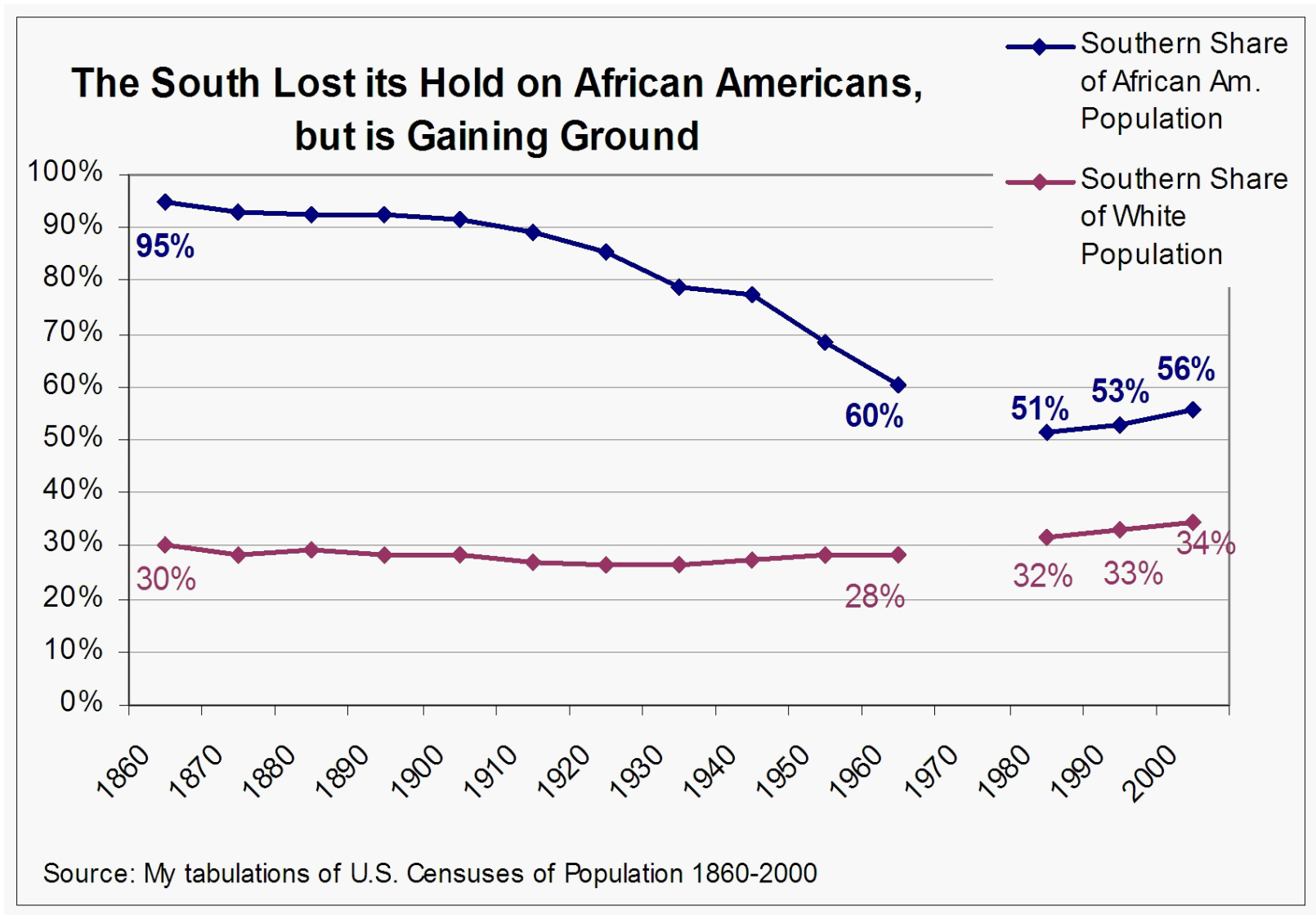

Chart 1

Table 5a: African Americans Consistently Left the South: 1870-1950

\begin{tabular}{|c|c|c|c|c|c|c|c|c|}
\hline & \multicolumn{4}{|c|}{ African American Net Migration } & \multicolumn{4}{|c|}{ White Net Migration } \\
\hline 10 Year Period & South & Northeast & N. Central & West & South & Northeast & N. Central & West \\
\hline $1870-1880$ & -68 & 26 & 42 & - & 91 & -374 & 26 & 257 \\
\hline $1880-1890$ & -88 & 61 & 28 & - & -271 & -240 & -43 & 554 \\
\hline $1890-1900$ & -185 & 136 & 49 & - & -30 & 101 & -445 & 374 \\
\hline $1900-1910$ & -194 & 109 & 63 & 22 & -69 & -196 & $-1,100$ & 1,375 \\
\hline $1910-1920$ & -555 & 242 & 281 & 32 & -663 & -74 & -145 & 880 \\
\hline $1920-1930$ & -903 & 435 & 426 & 42 & -704 & -177 & -464 & 1,345 \\
\hline $1930-1940$ & -480 & 273 & 152 & 55 & -558 & 55 & -747 & 1,250 \\
\hline $1940-1950$ & $-1,581$ & 599 & 626 & 356 & -866 & -659 & $-1,296$ & 2,822 \\
\hline \multicolumn{9}{|c|}{ Note: Figures in thousands. } \\
\hline \multicolumn{9}{|c|}{ Source: Collins, W. J. "When the Tide Turned: Immigration and the Delay of the Great Black Migration." } \\
\hline
\end{tabular}


Table 5b: Nearly 20\% of the South's African Americans Left Between 1940-50, but Less Than 5\% of Whites Ever Left

\begin{tabular}{c|r|r|r|c|c}
\hline \hline Census Year & \multicolumn{2}{|c|}{ Population } & Ten Year Period & \multicolumn{2}{c}{$\%$ of Population Lost } \\
\hline & White & Afr. Am. & & White & Afr. Am. \\
\hline 1870 & 8,109 & 4,043 & $1870-1880$ & $1 \%$ & $-2 \%$ \\
\hline 1880 & 10,424 & 5,409 & $1880-1890$ & $-3 \%$ & $-2 \%$ \\
\hline 1890 & 12,689 & 6,081 & $1890-1900$ & $0 \%$ & $-3 \%$ \\
\hline 1900 & 15,084 & 7,055 & $1900-1910$ & $0 \%$ & $-3 \%$ \\
\hline 1910 & 19,098 & 7,858 & $1910-1920$ & $-3 \%$ & $-7 \%$ \\
\hline 1920 & 21,792 & 7,963 & $1920-1930$ & $-3 \%$ & $-11 \%$ \\
\hline 1930 & 25,016 & 8,289 & $1930-1940$ & $-2 \%$ & $-6 \%$ \\
\hline 1940 & 27,557 & 8,694 & $1940-1950$ & $-3 \%$ & $-18 \%$ \\
\hline
\end{tabular}

Table 6: Twice as Many African Americans went South than North

\begin{tabular}{l|c|c}
\hline \hline & Gross Migration to South & Gross Migration to North \\
\hline African Americans & 665 & 341 \\
\hline Whites & 3,690 & 2,532 \\
\hline \multicolumn{2}{l}{ Note: Flows are reported in thousands. } \\
\hline \multicolumn{2}{l}{ Source: Author's tabulations of 5\% 2000 IPUMS. } \\
\hline \hline
\end{tabular}




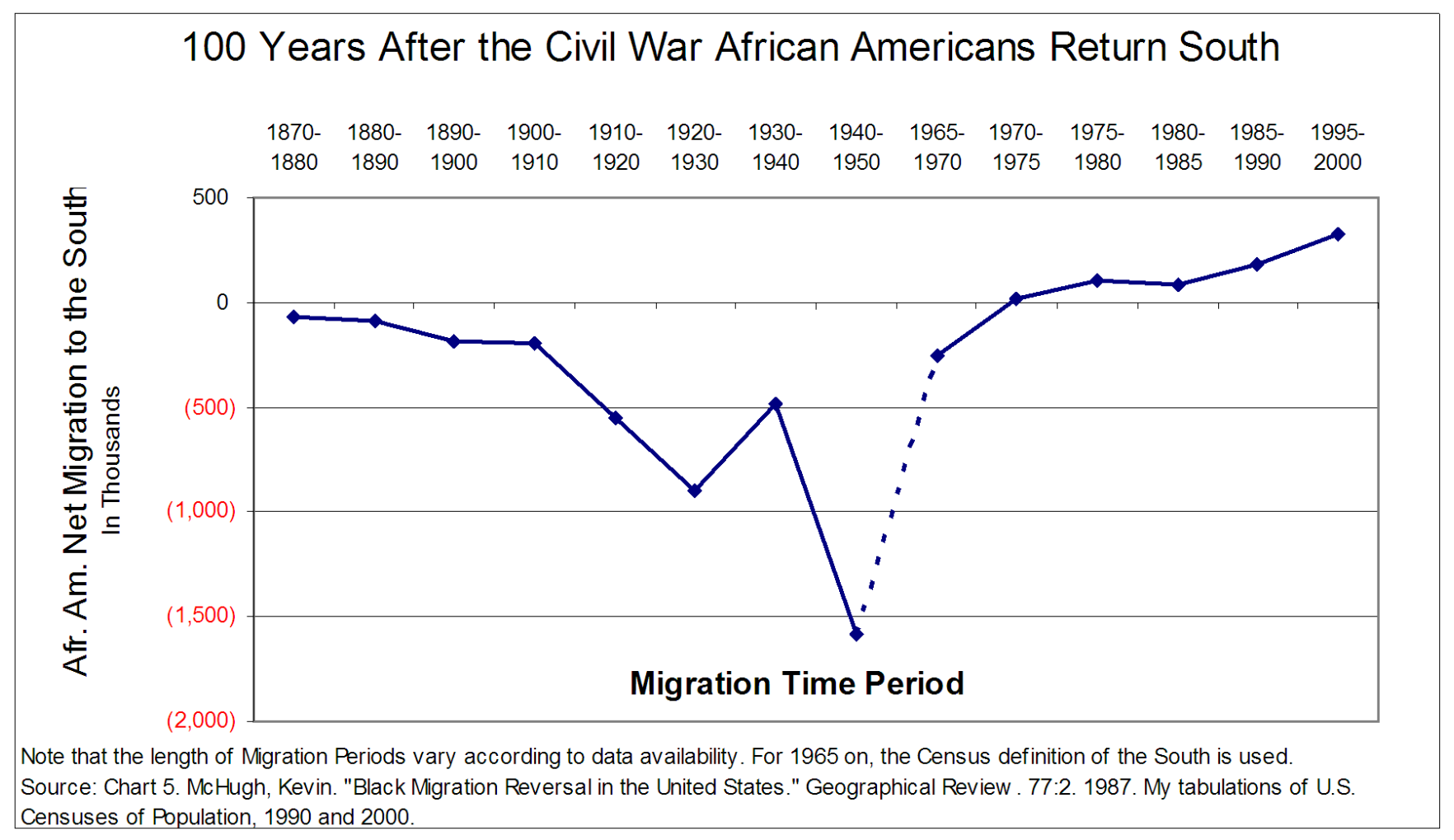

Chart 2 
Table 7: Most Southern States No Longer Lose Afr. Americans

\begin{tabular}{|c|c|c|c|c|c|}
\hline Region & State & \multicolumn{4}{|c|}{ Migration Time Period } \\
\hline & & $1965-70$ & $1975-80$ & $1985-90$ & $1995-00$ \\
\hline \multirow[t]{5}{*}{ Northeast } & Connecticut & 8,356 & $-3,012$ & -995 & $-5,089$ \\
\hline & Massachusetts & 7,701 & $-5,766$ & 3,123 & $-4,991$ \\
\hline & Pennsylvania & 2,182 & $-25,849$ & $-11,753$ & $-15,465$ \\
\hline & New Jersey & 24,936 & $-6,462$ & $-12,628$ & $-36,767$ \\
\hline & New York & 7,053 & $-128,143$ & $-141,372$ & $-160,008$ \\
\hline \multirow[t]{7}{*}{ Midwest } & Indiana & 9,177 & $-2,040$ & $-1,357$ & 7,059 \\
\hline & Missouri & 253 & $-10,428$ & $-4,704$ & 2,619 \\
\hline & Wisconsin & 7,910 & 6,964 & 6,786 & 885 \\
\hline & Ohio & 17,857 & $-16,503$ & $-1,357$ & $-3,711$ \\
\hline & Kansas & 1,248 & 4,215 & 3,099 & $-7,756$ \\
\hline & Michigan & 56,729 & 3,592 & $-19,301$ & $-13,922$ \\
\hline & Illinois & 12,670 & $-37,220$ & $-61,289$ & $-52,011$ \\
\hline \multirow[t]{15}{*}{ South } & Georgia & $-19,643$ & 29,616 & 83,666 & 127,906 \\
\hline & North Carolina & $-25,887$ & 14,456 & 36,005 & 52,108 \\
\hline & Florida & $-5,466$ & 15,900 & 53,855 & 45,303 \\
\hline & Texas & 5,009 & 47,685 & 7,651 & 45,026 \\
\hline & Maryland & 40,750 & 54,793 & 60,365 & 43,516 \\
\hline & Tennessee & $-15,577$ & 4,436 & 11,992 & 22,270 \\
\hline & Virginia & $-8,448$ & 22,295 & 55,143 & 19,205 \\
\hline & South Carolina & $-23,462$ & 9,238 & 3,210 & 16,207 \\
\hline & Alabama & $-53,854$ & $-7,843$ & $-9,828$ & 4,366 \\
\hline & Oklahoma & -946 & 7,192 & $-1,239$ & -301 \\
\hline & Kentucky & $-5,255$ & 5,500 & $-2,933$ & -479 \\
\hline & Arkansas & $-23,465$ & $-9,236$ & $-7,436$ & $-2,612$ \\
\hline & Mississippi & $-56,367$ & $-20,106$ & $-17,356$ & $-5,354$ \\
\hline & Louisiana & $-34,346$ & $-5,315$ & $-49,910$ & $-19,649$ \\
\hline & $\mathrm{DC}$ & $-18,876$ & $-58,454$ & $-42,928$ & $-35,131$ \\
\hline \multirow[t]{3}{*}{ West } & Washington & 3,550 & 10,681 & 7,036 & 4,464 \\
\hline & Colorado & 4,764 & 8,861 & 1,911 & -478 \\
\hline & California & 83,318 & 75,746 & 20.665 & $-52,300$ \\
\hline
\end{tabular}

Source: McHugh, Kevin. "Black Migration Reversal in the United States" Geographical

Review. 77:2. 1987. and author's tabulations of U.S. Censuses of Population 1990, 2000.

Note: States with an African American population of at least 100,000 in 1980. 
Table 8: Southern Cities Offered Better Economic Prospects

\begin{tabular}{l|c|c}
\hline \hline & Cities in the South & Cities in the North \\
\hline $\mathrm{N}$ & 88 & 134 \\
\hline Employment Growth ('92-'94) & $9.73 \%$ & $6.22 \%$ \\
\hline Unemployment Rate (1994) & $5.63 \%$ & $6.19 \%$ \\
\hline House Price Index (1994) & 118.34 & 136.24 \\
\hline \multicolumn{2}{l|}{ Source: Author's tabulations of CPS, BLS, and CMHPI data. } \\
\hline \hline
\end{tabular}

Table 9: Characteristics and Distribution of Southern Residents in 2000

\begin{tabular}{|c|c|c|c|c|c|c|c|c|}
\hline & \multicolumn{2}{|c|}{ African American } & \multicolumn{2}{|c|}{ African American } & \multicolumn{2}{|c|}{ All Other } & \multicolumn{2}{|c|}{ All Other } \\
\hline & \multicolumn{2}{|c|}{ Migrants to South } & \multicolumn{2}{|c|}{ NonMigrants in South } & \multicolumn{2}{|c|}{ Migrants to South } & \multicolumn{2}{|c|}{ NonMigrants in South } \\
\hline Median Age & & 35 & & 42 & & 36 & & 44 \\
\hline \multicolumn{9}{|l|}{ Degree Distribution } \\
\hline No High School & & $11 \%$ & & $22 \%$ & & $9 \%$ & & $14 \%$ \\
\hline High School & & $22 \%$ & & $31 \%$ & & $16 \%$ & & $25 \%$ \\
\hline Some College/Assoc. & & $40 \%$ & & $32 \%$ & & $29 \%$ & & $30 \%$ \\
\hline Bachelors & & $17 \%$ & & $11 \%$ & & $28 \%$ & & $19 \%$ \\
\hline Advanced & & $10 \%$ & & $5 \%$ & & $18 \%$ & & $11 \%$ \\
\hline Mean Income & & 45,644 & & 42,720 & & 66,648 & & 67,522 \\
\hline \multirow[t]{6}{*}{ Homeownership } & & $28 \%$ & & $47 \%$ & & $50 \%$ & & $75 \%$ \\
\hline & Atlanta & $(17 \%)$ & $\mathrm{DC}$ & $(9 \%)$ & $\mathrm{DC}$ & $(8.5 \%)$ & $\mathrm{DC}$ & $(6 \%)$ \\
\hline & $\mathrm{DC}$ & $(9 \%)$ & Atlanta & $(8 \%)$ & Atlanta & $(6 \%)$ & Houston & $(6 \%)$ \\
\hline & Norfolk & $(5 \%)$ & Houston & $(5 \%)$ & Tampa & $(5 \%)$ & Dallas & $(5 \%)$ \\
\hline & Baltimore & $(4 \%)$ & Baltimore & $(5 \%)$ & Dallas & $(5 \%)$ & Atlanta & $(5 \%)$ \\
\hline & Charlotte & $(3 \%)$ & Dallas & $(4 \%)$ & Orlando & $(4 \%)$ & St. Louis & $(4 \%)$ \\
\hline Top 11 & Houston & $(3 \%)$ & New Orleans & $(4 \%)$ & Houston & $(4 \%)$ & Tampa & $(3.5 \%)$ \\
\hline \multirow[t]{5}{*}{ Southern Cities (\%) } & Dallas & $(3 \%)$ & St. Louis & $(3.5 \%)$ & Ft. Laud. & $(3 \%)$ & Baltimore & $(3 \%)$ \\
\hline & Ft. Laud. & $(3 \%)$ & Memphis & $(3 \%)$ & W. Palm & $(3 \%)$ & Kansas City & $(3 \%)$ \\
\hline & Orlando & $(3 \%)$ & Norfolk & $(3 \%)$ & Raleigh & $(3 \%)$ & Ft. Worth & $(2.5 \%)$ \\
\hline & Raleigh & $(3 \%)$ & Richmond & $(2 \%)$ & Baltimore & $(3 \%)$ & San Antonio & $(2 \%)$ \\
\hline & Richmond & $(2.5 \%)$ & Charlotte & $(2 \%)$ & Charlotte & $(3 \%)$ & Orlando & $(2 \%)$ \\
\hline
\end{tabular}

Note: Residents under age 65. "All Other" is whites, Hispanics, Asian Americans. Residents in 2000.

African Americans originating in Southern Cities and migrating to other Southern Cities are not represented here.

Source: Author's tabulations of 5\% 2000 IPUMS. 
Table 10: Personal Characteristics Do Not Explain Within-Race Differences in Reactions to Intolerance

\begin{tabular}{|c|c|c|c|c|}
\hline & \multicolumn{2}{|c|}{ African Americans } & \multicolumn{2}{|c|}{ Whites } \\
\hline & $\begin{array}{c}\text { Migrants of } \\
\text { Northern Origin }\end{array}$ & $\begin{array}{c}\text { Migrants of } \\
\text { Southern Origin }\end{array}$ & $\begin{array}{c}\text { Migrants of } \\
\text { Northern Origin }\end{array}$ & $\begin{array}{c}\text { Migrants of } \\
\text { Southern Origin }\end{array}$ \\
\hline Mean Age & 36.0 & 34.5 & 36.4 & 37.2 \\
\hline$\%$ Female & $50 \%$ & $48 \%$ & $34 \%$ & $31 \%$ \\
\hline$\%$ Married & $31 \%$ & $33 \%$ & $47 \%$ & $50 \%$ \\
\hline$\%$ Blue Collar & $37 \%$ & $35 \%$ & $27 \%$ & $26 \%$ \\
\hline Mean Education $^{1}$ & 11.5 & 11.7 & 12.4 & 12.4 \\
\hline \% Stayed in Region & $59 \%$ & $79 \%$ & $77 \%$ & $71 \%$ \\
\hline \multicolumn{5}{|c|}{ Note: Under Age $65 .{ }^{1}$ Educational Attainment: $11=$ Some college, $12=$ Associates, $14=$ Bachelors } \\
\hline Source: Author's tabul & of $5 \%$ IPUMS. & & & \\
\hline
\end{tabular}

Table 11: Atlanta is a Favorite, But Other Southern Cities are also Popular

\begin{tabular}{|c|c|c|c|c|c|c|c|c|c|c|}
\hline Origin $\longrightarrow$ & New York & $\%$ & Chicago & $\%$ & Boston & $\%$ & Detroit & $\%$ & Los Angeles & $\%$ \\
\hline \multirow{17}{*}{$\begin{array}{c}\uparrow \\
\downarrow \\
\text { Destination } \\
\downarrow\end{array}$} & Nassau Co. & 10 & Gary & 6 & Brockton & 10 & Ann Arbor & 11 & Riverside & 27 \\
\hline & Atlanta & 8 & Atlanta & 6 & Atlanta & 9 & Atlanta & 9 & Las Vegas & 7 \\
\hline & $\mathrm{DC}$ & 5 & Minneapolis & 5 & $\mathrm{DC}$ & 5 & Las Vegas & 3 & Atlanta & 4 \\
\hline & Newark & 4 & Milwaukee & 4 & Providence & 5 & Lansing & 3 & Orange County & 4 \\
\hline & Norfolk & 3 & Indianapolis & 2 & New York & 5 & Chicago & 3 & Oakland & 3 \\
\hline & Ft. Laud. & 3 & Houston & 2 & Lowell & 3 & Kalamazoo & 3 & San Diego & 3 \\
\hline & Orlando & 2 & Memphis & 2 & Philadelphia & 3 & Birmingham & 2 & Phoenix & 2 \\
\hline & Philadelphia & 2 & Champaign & 2 & Orlando & 2 & Memphis & 2 & Houston & 2 \\
\hline & Baltimore & 2 & Los Angeles & 2 & Los Angeles & 2 & Norfolk & 2 & Dallas & 2 \\
\hline & Bergen & 2 & Bloomington & 1 & New Bedford & 2 & Nashville & 2 & $\mathrm{DC}$ & 2 \\
\hline & Richmond & 2 & St. Louis & 1 & Miami & 2 & Los Angeles & 2 & Sacramento & 2 \\
\hline & Raleigh & 2 & Las Vegas & 1 & Lawrence & 1 & Cleveland & 2 & Chicago & 1 \\
\hline & Charlotte & 2 & Phoenix & 1 & Fitchburg & 1 & Flint, MI & 2 & Seattle & 1 \\
\hline & Middlesex & 1 & Dallas & 1 & Tampa & 1 & New York & 2 & Bakersfield & 1 \\
\hline & Albany & 1 & Jackson & 1 & Raleigh & 1 & Grand Rapids & 1 & St. Louis & 1 \\
\hline & All 15 Cities & 49 & All 15 Cities & 39 & All 15 Cities & 53 & All 15 Cities & 45 & All 15 Cities & 64 \\
\hline & \multicolumn{10}{|c|}{ Source: Author's tabulations of 5\% IPUMS. } \\
\hline
\end{tabular}


Table 12: Some Very Intolerant Places Have Shown Progress

\begin{tabular}{|c|c|c|}
\hline City & Share Responding Intolerantly $^{1}$ & \% Change from Prior Period ${ }^{2}$ \\
\hline El Dorado & $16 \%$ & $-58 \%$ \\
\hline Los Angeles & $17 \%$ & $-41 \%$ \\
\hline Atlanta & $30 \%$ & $-40 \%$ \\
\hline Birmingham & $41 \%$ & $-37 \%$ \\
\hline Boston & $19 \%$ & $-36 \%$ \\
\hline Philadelphia & $22 \%$ & $-29 \%$ \\
\hline St. Louis & $28 \%$ & $-26 \%$ \\
\hline Baltimore & $24 \%$ & $-25 \%$ \\
\hline Buffalo & $27 \%$ & $-20 \%$ \\
\hline Newark & $22 \%$ & $-18 \%$ \\
\hline Chicago & $28 \%$ & $-16 \%$ \\
\hline Denver & $17 \%$ & $-16 \%$ \\
\hline Houston & $32 \%$ & $-13 \%$ \\
\hline Knoxville & $38 \%$ & $-4 \%$ \\
\hline Detroit & $29 \%$ & $0 \%$ \\
\hline All Areas & $26 \%$ & $-28 \%$ \\
\hline
\end{tabular}

Table 13: Assaults on White Police Officers and Jews are Strong Instruments

\begin{tabular}{|c|c|c|}
\hline Endogenous Variable & Instrument & F-Statistic \\
\hline $\begin{array}{c}\text { Anti-African American } \\
\text { Hate Crime Rate }\end{array}$ & $\begin{array}{l}\text { Assaults on White Police } \\
\text { Officers per Afr. Am. }\end{array}$ & $1.4 \times 10^{6}$ \\
\hline $\begin{array}{c}\text { Total Anti-African American } \\
\text { Hate Crimes }\end{array}$ & $\begin{array}{c}\text { Total Anti-Jew } \\
\text { Hate Crimes }\end{array}$ & $2.5 \times 10^{5}$ \\
\hline
\end{tabular}

Table 14: African American Migrants are Less Disposed to Crime

\begin{tabular}{l|c|c|c|c}
\hline \hline \multirow{2}{*}{} & \multicolumn{2}{|c|}{ African Americans } & \multicolumn{2}{c}{ Whites } \\
\cline { 2 - 5 } & Migrants & NonMigrants & Migrants & NonMigrants \\
\hline Unemployment & $7.1 \%$ & $7.3 \%$ & $3.2 \%$ & $2.7 \%$ \\
\hline Mean Education Attainment & 11.2 & 10 & 12 & 11 \\
\hline$\%<$ High School Degree & $14 \%$ & $28 \%$ & $8 \%$ & $16 \%$ \\
\hline Median Income & $\$ 31,000$ & $\$ 29,000$ & $\$ 44,330$ & $\$ 45,220$ \\
\hline Note: All Ages. Educational Attainment 11= Some college 12= Associates $14=$ Bachelors \\
\hline Source: Author's tabulations of 5\% 2000 IPUMS.
\end{tabular}




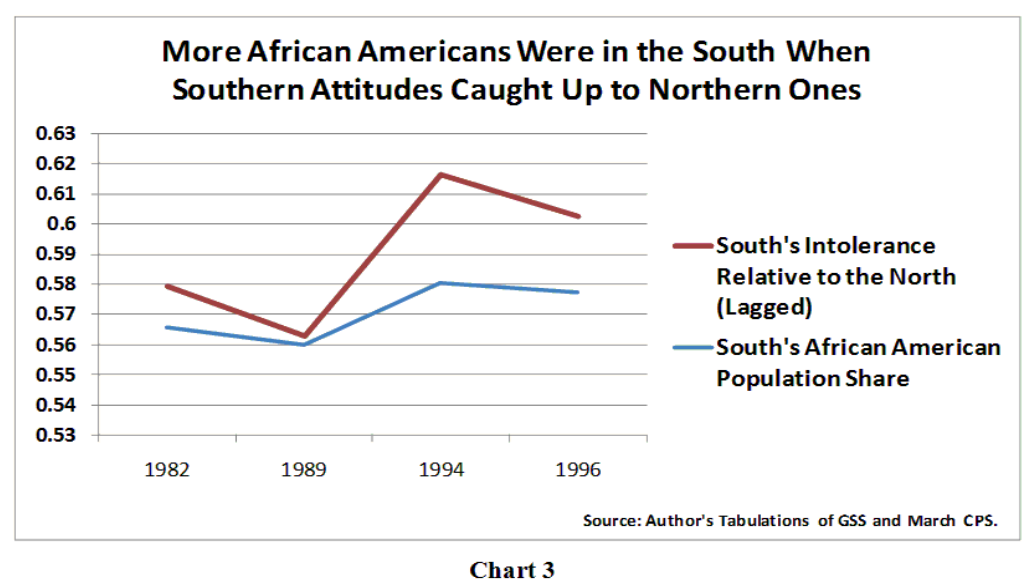

Table 15: Afr. American Migrants are More Racially Tolerant than NonMigrants

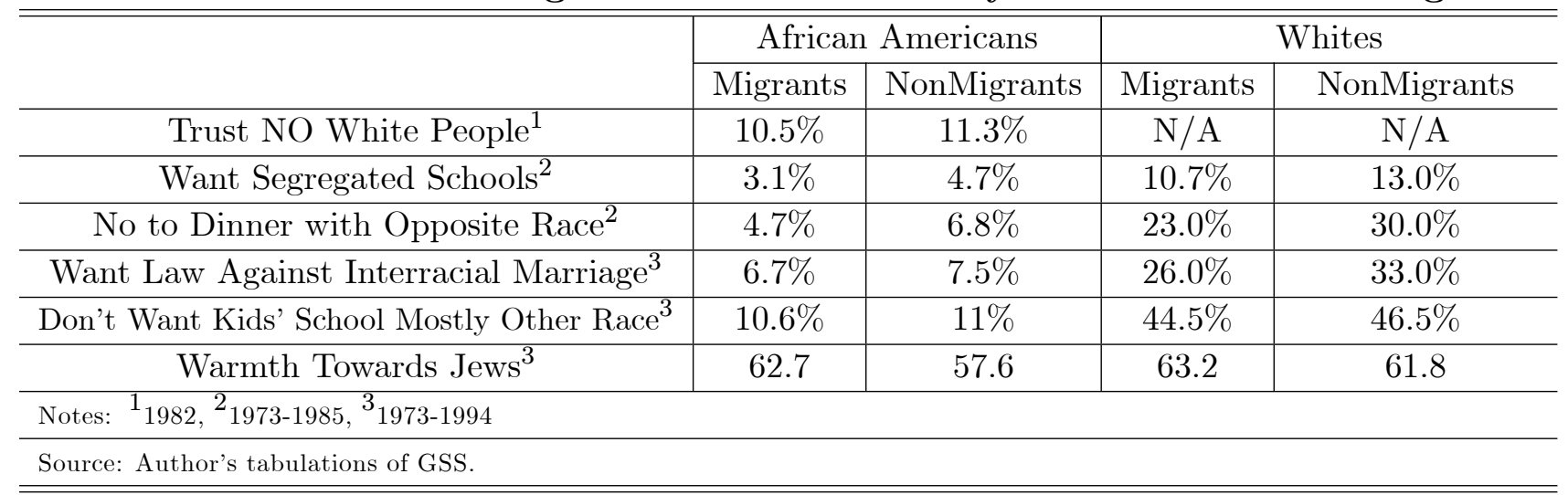




\section{Data Appendix}

The main source of individual migration data for this study is the $20005 \%$ Census (IPUMS). For robustness purposes, I draw an additional individual migration datasets from the 2000 CPS, and pool the 1996-2000 CPS surveys, but use the same specification. In the estimations, I identify migrants as those moving from one metro area to a different metro area between 1995 and 2000. As a general point affecting any migration study, Nakosteen and Zimmer [1980] show a fundamental difference between nonmigrants and migrants beyond the observable ones in a model. This problem of self-selection poses a potential bias in migration decisions that are modeled using both nonmigrants and migrants (Heckman [1979]). I explain the destination choices of individuals in the selected group comparing them only to other individuals with this same selection. There are 261,202 such non-military migrant households in the IPUMS dataset.

Observed personal characteristics in the IPUMS include age, years of education, race, gender, marital status. I use the race information to form a race indicator for African Americans; those who both report their race as African American and report absence of Hispanic origin are given the value 1 for this dummy. Female respondents correspond to 1 in the gender indicator; the married indicator is 1 if the spouse is present.

I obtained data on racial attitudes from the General Social Survey (GSS) administered by the National Opinions Research Center (NORC) at the University of Chicago for the years 1973 to 1993 . Measuring racial tension in different areas is key to my research question yet these data do not explicitly contain geographic location or employ standard metro area codes. The decoding procedure is extremely costly. In addition to the coding algorithm changing for different sample years, it also changes within a sample. Furthermore, the decoded values are not designed to correspond to the standard metro area codes used in the IPUMS micro data. That said, the standard metro area codes are loosely a function of the alphabetical order of the metro names, thus an alphabetical listing of the GSS areas could facilitate the matching process. Unfortunately, the only 
source of the GSS metro names paired with their non-standard codes is in hard copy and out of alphabetical order. Thus, manual data entry of the GSS metro names and codes was necessary to match them to the metro areas in the micro data. Finally, the GSS covered several metro areas only partially, and the decoding documentation detailed only the county names without the names of the metro areas these counties fall into. To match the counties in the GSS to their corresponding metro areas in the micro data required searching the documentation of the standard metro area definitions.

All other area characteristics collected outside the IPUMS also required matching by metro area codes. The Uniform Crime Reporting Program (UCRP) provided FBI data on hate crime activity. I constructed a variable for general crimes defined as the sum of burglary, larceny, robbery, and motor vehicle theft also using the UCRP. I used the Bureau of Labor Statistics (BLS) web tables to compile 1994 metro area unemployment rates. Employment and population growth were based on the 1992 and 1994 CPS. The 1994 Consumer Mortgage Home Price Index (CMHPI) provided metro area housing price data. The average temperature and average temperature spread (difference between average high and average low) are also included. Weatherbase ${ }^{S M}$ organizes data from the National Climatic Data Center (NCDC), and I used their web tables for metro area temperature data. Geographic coordinates to calculate the distance between origin and destination choices were taken from Wikipedia.com.

Finally, because the race of the native population is not an attribute that changes as a result of new arrivals, I calculated the African American population share of native residents in each metro area using the IPUMS. Native residents are those who were in the location before the migration period started. I also used the number of native residents before the migrants arrived as the total population variable. 
Table 16: Summary Statistics of City Characteristics

\begin{tabular}{|c|c|c|c|c|}
\hline & Mean & Std. Dev. & Min & Max \\
\hline Per Capita Anti-African American Hate Crimes & 0.0015 & 0.0032 & 0.0000 & 0.0217 \\
\hline Share of Whites with Racially Intolerant Attitudes & 0.2338 & 0.0922 & 0.1013 & 0.5085 \\
\hline Growth in Racially Intolerant Attitudes & -0.2307 & 0.1857 & -0.6070 & 0.5954 \\
\hline South Indicator & 0.4045 & 0.4908 & 0.0000 & 1.0000 \\
\hline African American Population Share & 0.1073 & 0.1072 & 0.0006 & 0.5056 \\
\hline Segregation Index & 60.6314 & 11.1576 & 31.7000 & 87.9000 \\
\hline Employment Growth & 0.0630 & 0.1606 & -0.4412 & 0.7302 \\
\hline Unemployment Rate & 0.0632 & 0.0319 & 0.0210 & 0.3110 \\
\hline House Price Index & 129.3996 & 20.1087 & 86.3500 & 213.3000 \\
\hline City Relative Log Wage & 1.6493 & 0.5981 & -1.8750 & 5.2718 \\
\hline City Relative Wage Penalty for Being African American & -0.1226 & 0.3090 & -2.3551 & 1.5092 \\
\hline Per Capita General Crimes (Excluding Hate Crimes) & 0.0715 & 0.0592 & 0.0000 & 0.6156 \\
\hline Population in $1000 \mathrm{~s}$ & 589.5240 & 975.1158 & 45.7320 & 7674.3900 \\
\hline Population Growth & 0.0634 & 0.1985 & -0.3331 & 1.1096 \\
\hline Average Temperature & 56.8527 & 8.3352 & 39.0000 & 76.0000 \\
\hline Average Temperature Spread & 20.7877 & 3.8288 & 0.0000 & 32.0000 \\
\hline
\end{tabular}

